\title{
Effectiveness of adalimumab in treating patients with ankylosing spondylitis associated with enthesitis and peripheral arthritis
}

\author{
Martin Rudwaleit ${ }^{*}$, Pascal Claudepierre ${ }^{2}$, Martina Kron ${ }^{3}$, Sonja Kary ${ }^{3}$, Robert Wong ${ }^{4,5}$, Hartmut Kupper ${ }^{3}$
}

\begin{abstract}
Introduction: The purpose of this study was to investigate the effectiveness of adalimumab in enthesitis and peripheral arthritis in patients with ankylosing spondylitis (AS).

Methods: Adults with active AS (Bath ankylosing spondylitis disease activity index [BASDAl] $\geq 4$ ) received adalimumab $40 \mathrm{mg}$ every other week with standard antirheumatic therapies in a 12-week, open-label study. Effectiveness in enthesitis was assessed using the Maastricht ankylosing spondylitis enthesitis score (MASES, 0-13) and by examining the plantar fascia in patients with enthesitis ( $\geq 1$ inflamed enthesis) at baseline; effectiveness in peripheral arthritis was evaluated using tender and swollen joint counts (TJC, 0-46; SJC, 0-44) in patients with peripheral arthritis ( $\geq 1$ swollen joint) at baseline. Overall effectiveness measures included Assessment of SpondyloArthritis International Society $20 \%$ response (ASAS20).
\end{abstract}

Results: Of 1,250 patients enrolled, 686 had enthesitis and 281 had peripheral arthritis. In 667 patients with MASES $\geq 1$ at baseline, the median MASES was reduced from 5 at baseline to 1 at week 12 . At week 12, inflammation of the plantar fascia ceased in 122 of 173 patients with inflammation at baseline. The median TJC in 281 patients with SJC $\geq 1$ at baseline was reduced from 5 at baseline to 1 at week 12; the median SJC improved from 2 to 0 . ASAS20 responses were achieved by $70.5 \%$ of 457 patients with no enthesitis and no arthritis; $71.0 \%$ of 512 patients with only enthesitis; $68.0 \%$ of 107 patients with only arthritis; and $66.7 \%$ of 174 patients with both.

Conclusions: Treatment with adalimumab improved enthesitis and peripheral arthritis in patients with active AS.

Trial registration: ClinicalTrials.gov NCT00478660.

\section{Introduction}

In addition to chronic inflammation of the spine, extraaxial manifestations are common features in patients with ankylosing spondylitis (AS). Enthesitis and peripheral arthritis, predominantly of the lower limbs, occur in up to $50 \%$ of patients with AS during the course of the disease [1-5]. These extra-axial manifestations of AS contribute to the burden of the disease [6,7].

Nonsteroidal anti-inflammatory drugs (NSAIDs) remain first-line agents for the treatment of AS and can be used for the treatment of enthesitis [8]. Disease-modifying antirheumatic drugs (DMARDs) do not have a satisfactory effect on axial disease. Sulfasalazine has

\footnotetext{
*Correspondence: publications@jkmed.com

${ }^{1}$ Charité-University Medicine Berlin, Benjamin Franklin Campus, Medical Department I, Rheumatology, Hindenburgdamm 30, 12203 Berlin, Germany
}

some effect on extra-axial arthritis [9] but its benefit for treating enthesitis does not outweigh its risks [8]. Tumor necrosis factor (TNF) antagonists, including the monoclonal antibodies adalimumab and infliximab and the TNF-receptor construct etanercept, are highly effective agents for the treatment of patients who have active AS despite NSAID treatment [9-18].

In a 24-week, randomized, double-blind, placebo-controlled study of patients with active AS, 152 adalimumab-treated patients experienced a significant reduction in enthesitis compared with 81 placebo-treated patients but no significant improvement in peripheral arthritis [15]. Similarly, other randomized controlled trials (RCTs) of TNF antagonists have not consistently demonstrated significant improvements in both enthesitis and peripheral arthritis for TNF-antagonist-treated 
patients compared with placebo-treated patients $[10,12,14,16,17]$. Only in one RCT of infliximab in AS were significant improvements in both tender joint count (TJC) and swollen joint count (SJC) observed [10]. We evaluated the effects of adalimumab on enthesitis and peripheral arthritis in a large cohort of 1,250 patients with active AS who were enrolled in the openlabel RHAPSODY (Review of Safety and Effectiveness with Adalimumab in Patients with Active Ankylosing Spondylitis) study [1].

\section{Materials and methods}

The patient sample and methods of the RHAPSODY study, an open-label, multicenter study conducted at 211 centers in 15 European countries, were previously described in detail [1]. Independent ethics committees at all participating centers approved the study, and all participating patients gave written informed consent.

\section{Patients}

Patients who were at least 18 years old and who had AS according to the modified 1984 New York Criteria for AS [19] and active disease defined by a Bath Ankylosing Spondylitis Disease Activity Index (BASDAI) score of at least 4 [20] were eligible for this study if at least one NSAID or (if stipulated by national guidelines) at least two NSAIDs had failed to control their disease. Patients were permitted to continue current AS therapy with NSAIDs, DMARDs, analgesics, and glucocorticoids ( $\leq$ $10 \mathrm{mg} / \mathrm{d}$ of prednisone equivalent) during the study. Intra-articular injections or infiltrations of extra-axial joints and tendons were not permitted within 28 days and injections of sacroiliac joints were not permitted within 14 days before screening or during the study. Previous anti-TNF therapy was permitted provided that etanercept had been discontinued at least 3 weeks or infliximab had been discontinued at least 2 months before the first adalimumab injection.

\section{Study design}

At baseline, clinicians documented the presence or absence of enthesitis and peripheral arthritis. Enthesitis was defined as at least 1 inflamed enthesis in the Maastricht Ankylosing Spondylitis Enthesitis Score (MASES) (0 to 13) [21] or of the plantar fascia of the foot. Peripheral arthritis was defined as an SJC of at least 1 (0 to 44, excluding hip joints).

Patients self-administered $40 \mathrm{mg}$ of adalimumab (Abbott Laboratories, Abbott Park, IL, USA) subcutaneously every other week for 12 weeks. The treatment effect of adalimumab for enthesitis was assessed by measuring the change from baseline to week 12 in the MASES (for patients with MASES of at least 1 at baseline) and the change from baseline to week 12 in the percentage of patients with enthesitis of the plantar fascia (for patients with inflammation of the plantar fascia at baseline). The treatment effect of adalimumab for peripheral arthritis was assessed by measuring the change in TJCs (0 to 46) and SJCs from baseline to weeks 2, 6, and 12 . Overall adalimumab effectiveness was measured using the Assessment of SpondyloArthritis International Society $20 \%$ and $40 \%$ responses (ASAS20 and ASAS40, respectively) [20,22] and using a $50 \%$ improvement in the BASDAI (BASDAI 50) $[23,24]$. In addition, absolute values at each study visit (weeks 2 , 6 , and 12, as applicable) and changes from baseline were calculated for BASDAI (0 to 10) [20], Bath Ankylosing Spondylitis Functional Index (BASFI) (0 to 10) [25], the Patient's Global Assessment of disease activity (PaGA) (based on a visual analog scale of 0 to $100 \mathrm{~mm}$ ), and C-reactive protein (CRP) serum concentration.

\section{Statistical analysis}

Patients who had received at least one injection of adalimumab were included in the analyses. Observed data were used for all effectiveness analyses, and week 12 was specified as the endpoint. Patients with MASES of at least 1 and patients with SJC of at least 1 were stratified by sex (male or female), HLA-B27 positivity (positive or negative), and concomitant DMARD therapy (yes or no) to analyze changes in MASES, TJC, and SJC. The effects of adalimumab on AS disease activity and functional disability were evaluated in four subgroups: (a) patients with no enthesitis and no peripheral arthritis, (b) patients with enthesitis and no peripheral arthritis, (c) patients with peripheral arthritis and no enthesitis, and (d) patients with both enthesitis and peripheral arthritis.

Descriptive analyses were performed by calculating counts and percentages for qualitative data and by calculating medians and first and third quartiles for quantitative data. For the three patient groups without arthritis and enthesitis, with either peripheral arthritis or enthesitis, and with both, the Jonckheere-Terpstra test was applied to test for trends in baseline values and absolute changes from baseline to week 12 in BASDAI, BASFI, PaGA, and CRP. For the median absolute change from baseline to week 12 in MASES, TJC, SJC, BASDAI, BASFI, PaGA, and CRP, nonparametric 95\% confidence intervals (CIs) were calculated. Correlations between improvements in AS overall (measured by changes in BASDAI and in BASFI) and improvements in extra-axial manifestations (measured by changes in MASES, plantar fascia, TJC, and SJC) at week 12 were assessed using the Spearman rank order correlation coefficient. 


\section{Results}

\section{Patient disposition}

A total of 1,250 patients with AS were enrolled. Through week $12,7.3 \%$ of the patients discontinued adalimumab therapy [1]. Of enrolled patients, 457 (36.6\%) patients had no enthesitis and no peripheral arthritis at baseline (Figure 1). Enthesitis (MASES or plantar fascia or both of at least 1) was reported in 686 (54.9\%) patients. At least one inflamed enthesis in MASES was documented for 667 patients, and inflammation of the plantar fascia was reported for 173 patients, including 19 patients without enthesitis in MASES. The distribution of enthesitis sites at baseline is shown in Figure 2. Of the 281 (22.5\%) patients with peripheral arthritis (SJC of at least 1) at baseline, 96 had tenderness of the hip joint, indicating possible hip involvement. Enthesitis without peripheral arthritis was documented in 512 (41.0\%) patients; arthritis without enthesitis was reported in 107 (8.6\%) patients. Both enthesitis and peripheral arthritis were present in 174 of $1,250(13.9 \%)$ patients.

\section{Baseline characteristics}

\section{Patients with enthesitis or peripheral arthritis or both}

The mean age of patients and the mean duration of AS were similar between patient subgroups, irrespective of the presence of enthesitis and arthritis (Table 1). The percentage of men was lower in the patient subgroups with enthesitis or peripheral arthritis or both (range,
$58.0 \%$ to $69.2 \%$ ) than in the subgroup with no enthesitis and no arthritis $(80.7 \%)$. The percentage of patients with HLA-B27 was lower in the subgroup with both enthesitis and peripheral arthritis (76.0\%) than in the other subgroups (range, $82.2 \%$ to $84.1 \%$ ). The patient subgroup with peripheral arthritis and no enthesitis had the greatest percentages of patients receiving concomitant therapy with DMARDs (45.8\%) or glucocorticoids (29.9\%). Median BASDAI, BASFI, and PaGA scores were lower in patients with no enthesitis and no arthritis than in patients with enthesitis or peripheral arthritis or both $(P<0.005)$ (Table 2$)$.

\section{Patients with MASES of at least 1 at baseline}

The median MASES was 5 for the 667 patients with MASES of at least 1 at baseline (Table 3 ). The median MASESs were 4 for 432 male patients and 7 for 236 female patients, 5 for both 523 HLA-B27-positive patients and 126 HLA-B27-negative patients, and 5 for 499 patients without concomitant DMARD treatment at baseline and 4 for 168 patients with concomitant DMARD therapy at baseline.

\section{Patients with enthesitis of plantar fascia}

The percentages of patients with enthesitis of the plantar fascia were $11.8 \%$ in men (105 of 891 men) and $18.9 \%$ in women (68 of 359 women).

Patients with a swollen joint count of at least 1 at baseline The median TJCs and SJCs were 5 and 2, respectively, at baseline for 281 patients with an SJC of at least 1

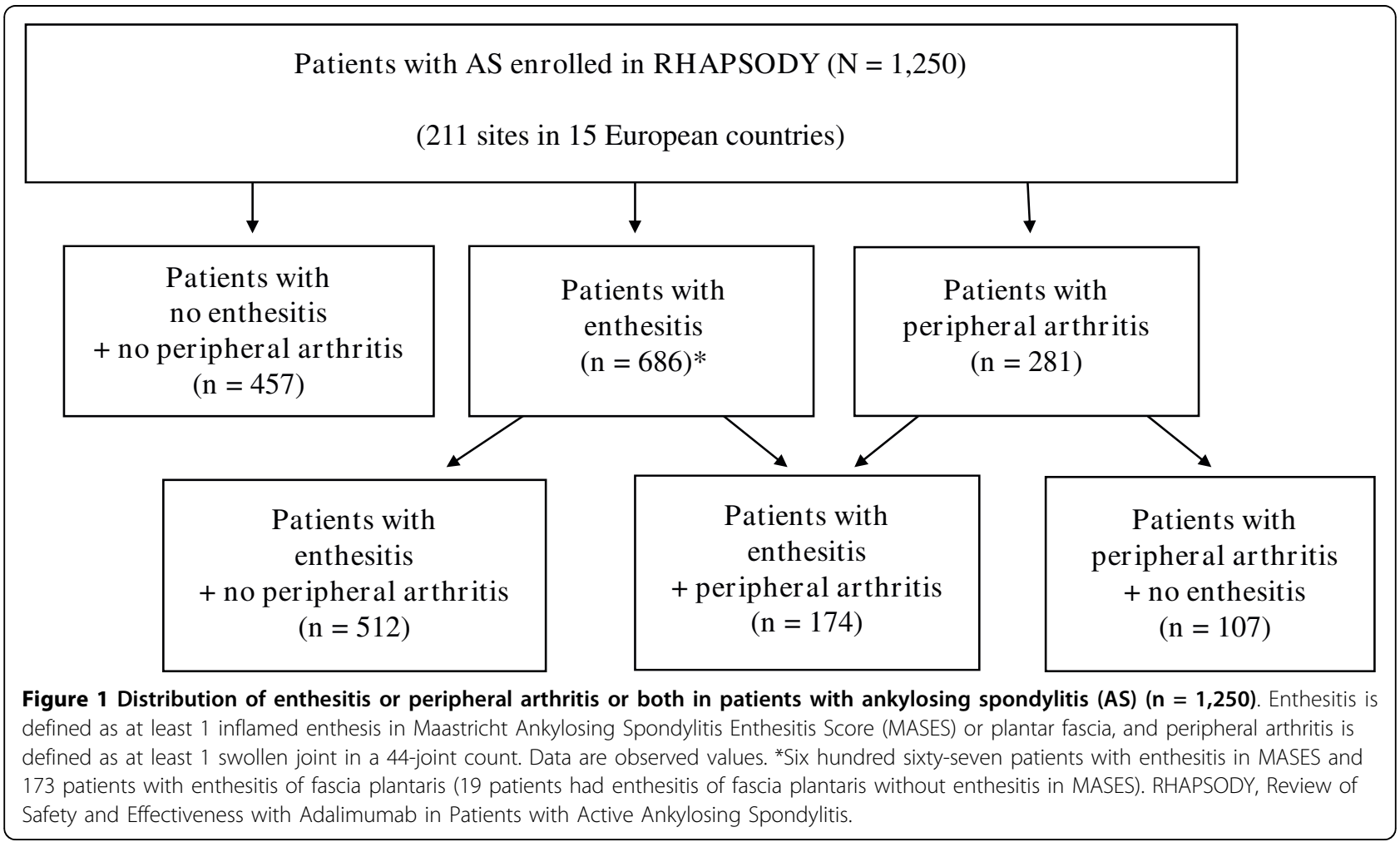




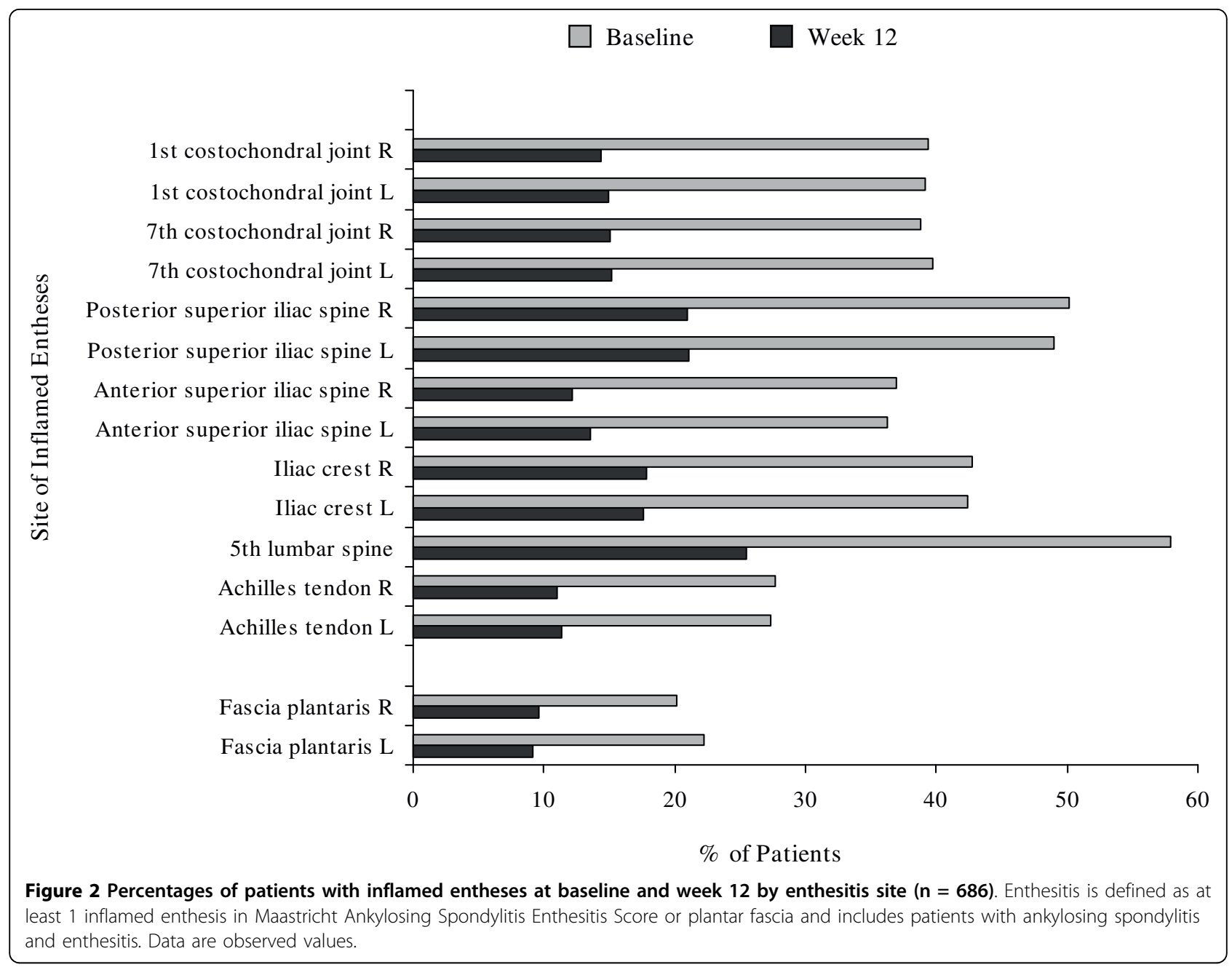

Table 1 Baseline characteristics in patients with ankylosing spondylitis by subgroup of enthesitis or peripheral arthritis or both

\begin{tabular}{|c|c|c|c|c|}
\hline \multirow[b]{2}{*}{ Characteristic } & \multicolumn{4}{|c|}{ Patient subgroups } \\
\hline & $\begin{array}{c}\text { No enthesitis } \\
+ \text { no arthritis }(n=457)\end{array}$ & $\begin{array}{c}\text { Enthesitis } \\
+ \text { no arthritis }(n=512)\end{array}$ & $\begin{array}{c}\text { Arthritis } \\
+ \text { no enthesitis }(n=107)\end{array}$ & $\begin{array}{l}\text { Enthesitis } \\
+ \text { arthritis } \\
(\mathrm{n}=174)\end{array}$ \\
\hline Age, years & $43.1 \pm 11.2$ & $42.7 \pm 11.1$ & $46.0 \pm 11.9$ & $46.1 \pm 12.3$ \\
\hline Males, percentage & 80.7 & 67.8 & 69.2 & 58.0 \\
\hline HLA-B27-positive, percentage & 83.7 & 82.2 & 84.1 & 76.0 \\
\hline AS duration, years & $10.9 \pm 9.4$ & $10.5 \pm 9.7$ & $12.3 \pm 10.6$ & $11.8 \pm 10.5$ \\
\hline Advanced AS, percentage & 25.2 & 28.4 & 27.6 & 26.5 \\
\hline Concomitant NSAIDs, percentage & 74.0 & 76.8 & 73.8 & 68.4 \\
\hline Concomitant DMARDs, percentage & 21.7 & 22.1 & 45.8 & 35.6 \\
\hline Concomitant glucocorticoids ${ }^{\mathrm{a}}$, percentage & 10.1 & 10.9 & 29.9 & 20.1 \\
\hline Prior TNF-antagonist therapy, percentage & 25.8 & 25.0 & 27.1 & 29.3 \\
\hline
\end{tabular}

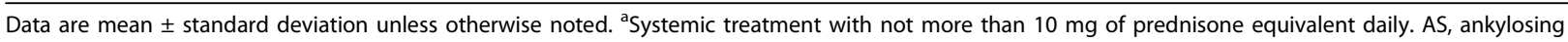
spondylitis; DMARD, disease-modifying antirheumatic drug; NSAID, nonsteroidal anti-inflammatory drug; TNF, tumor necrosis factor. 
Table 2 Effectiveness of adalimumab at week 12 in patients with ankylosing spondylitis by subgroup of enthesitis or peripheral arthritis or both

\begin{tabular}{|c|c|c|c|c|c|}
\hline & $\begin{array}{l}\text { No enthesitis } \\
+ \text { no arthritis } \\
(n=457)\end{array}$ & $\begin{array}{c}\text { Enthesitis } \\
+ \text { no arthritis } \\
(n=512)\end{array}$ & $\begin{array}{c}\text { Arthritis } \\
+ \text { no enthesitis } \\
(n=107)\end{array}$ & $\begin{array}{c}\text { Enthesitis } \\
+ \text { arthritis } \\
(\mathrm{n}=174)\end{array}$ & $P$ value $^{a}$ \\
\hline & \multicolumn{4}{|c|}{ Median First quartile, third quartile [95\% confidence interval] } & \\
\hline \multicolumn{6}{|l|}{ BASDAI, 0 to 10} \\
\hline Baseline & $\begin{array}{c}5.9 \\
4.9,6.9\end{array}$ & $\begin{array}{c}6.4 \\
5.4,7.5\end{array}$ & $\begin{array}{c}6.7 \\
5.7,7.7\end{array}$ & $\begin{array}{c}6.6 \\
5.7,7.6\end{array}$ & $<0.001$ \\
\hline Week 12 & $\begin{array}{c}2.1 \\
0.8,4.1\end{array}$ & $\begin{array}{c}2.6 \\
1.1,5.1\end{array}$ & $\begin{array}{c}3.1 \\
1.5,4.8\end{array}$ & $\begin{array}{c}2.7 \\
1.2,5.0\end{array}$ & \\
\hline Change from baseline to week12 & $\begin{array}{c}-3.6 \\
-4.8,-1.7 \\
{[-3.8 \text { to }-3.3]} \\
\end{array}$ & $\begin{array}{c}-3.4 \\
-4.9,-1.5 \\
{[-3.7 \text { to }-3.1]} \\
\end{array}$ & $\begin{array}{c}-3.1 \\
-5.0,-1.8 \\
{[-4.0 \text { to }-2.7]} \\
\end{array}$ & $\begin{array}{c}-3.5 \\
-4.9,-1.7 \\
{[-3.7 \text { to }-2.9]} \\
\end{array}$ & 0.813 \\
\hline \multicolumn{6}{|l|}{ BASFI, 0 to 10} \\
\hline Baseline & $\begin{array}{c}4.9 \\
3.4,6.7\end{array}$ & $\begin{array}{c}5.7 \\
4.0,7.3\end{array}$ & $\begin{array}{c}5.8 \\
3.7,7.0\end{array}$ & $\begin{array}{c}6.0 \\
4.3,7.5\end{array}$ & $<0.001$ \\
\hline Week 12 & $\begin{array}{c}2.2 \\
1.0,4.3\end{array}$ & $\begin{array}{c}2.7 \\
1.0,5.1\end{array}$ & $\begin{array}{c}3.1 \\
1.4,5.3\end{array}$ & $\begin{array}{c}2.8 \\
1.3,5.3\end{array}$ & \\
\hline Change from baseline to week 12 & $\begin{array}{c}-1.9 \\
-3.6,-0.7 \\
{[-2.1 \text { to }-1.7]}\end{array}$ & $\begin{array}{c}-2.1 \\
-3.8,-0.6 \\
{[-2.4 \text { to }-1.7]}\end{array}$ & $\begin{array}{c}-1.8 \\
-3.2,-0.7 \\
{[-2.2 \text { to }-1.5]}\end{array}$ & $\begin{array}{c}-1.9 \\
-3.7,-0.5 \\
{[-2.2 \text { to }-1.5]}\end{array}$ & 0.828 \\
\hline \multicolumn{6}{|c|}{ Patient's Global Assessment of disease activity, 0- to $100-\mathrm{mm}$ visual analog scale } \\
\hline Baseline & $\begin{array}{c}67 \\
49,80\end{array}$ & $\begin{array}{c}71 \\
53,83\end{array}$ & $\begin{array}{c}72 \\
54,81\end{array}$ & $\begin{array}{c}72 \\
53,83\end{array}$ & 0.004 \\
\hline Week 12 & $\begin{array}{c}21 \\
8,46\end{array}$ & $\begin{array}{c}24 \\
8,52\end{array}$ & $\begin{array}{c}25 \\
11,48\end{array}$ & $\begin{array}{c}26 \\
10,52\end{array}$ & \\
\hline Change from baseline to week 12 & $\begin{array}{c}-35 \\
-58,-14 \\
{[-40 \text { to }-32]} \\
\end{array}$ & $\begin{array}{c}-38 \\
-59,-15 \\
{[-42 \text { to }-34]} \\
\end{array}$ & $\begin{array}{c}-39 \\
-61,-13 \\
{[-48 \text { to }-26]} \\
\end{array}$ & $\begin{array}{c}-33 \\
-57,-12 \\
{[-41 \text { to }-24]} \\
\end{array}$ & 0.806 \\
\hline \multicolumn{6}{|l|}{ C-reactive protein ${ }^{\mathrm{b}}, \mathrm{mg} / \mathrm{dL}$} \\
\hline Baseline & $\begin{array}{c}1.2 \\
0.6,2.5\end{array}$ & $\begin{array}{c}1.2 \\
0.5,2.4\end{array}$ & $\begin{array}{c}1.5 \\
0.8,3.6\end{array}$ & $\begin{array}{c}1.3 \\
0.6,3.4\end{array}$ & 0.448 \\
\hline Week 12 & $\begin{array}{c}0.4 \\
0.2,0.8\end{array}$ & $\begin{array}{c}0.4 \\
0.2,0.8\end{array}$ & $\begin{array}{c}0.6 \\
0.2,1.5\end{array}$ & $\begin{array}{c}0.4 \\
0.1,0.9\end{array}$ & \\
\hline Change from baseline to week 12 & $\begin{array}{c}-0.7 \\
-2.1,-0.1 \\
{[-0.9 \text { to }-0.6]}\end{array}$ & $\begin{array}{c}-0.8 \\
-1.7,-0.2 \\
{[-1.0 \text { to }-0.7]}\end{array}$ & $\begin{array}{c}-1.4 \\
-1.7,-0.1 \\
{[-1.0 \text { to }-0.4]}\end{array}$ & $\begin{array}{c}-0.7 \\
-2.6,-0.1 \\
{[-1.3 \text { to }-0.4]}\end{array}$ & 0.857 \\
\hline
\end{tabular}

${ }^{\mathrm{a}} P$ values (two-sided) are based on Jonckheere-Terpstra tests for trends between subgroups without enthesitis and peripheral arthritis, with either enthesitis or peripheral arthritis, and with both. ${ }^{b}$ Reference value is $0.4 \mathrm{mg} / \mathrm{dL}$. BASDAl, Bath Ankylosing Spondylitis Disease Activity Index; BASFI, Bath Ankylosing Spondylitis Functional Index.

(Table 3). Knees (35\% of joints), ankles (35\%), and hips (30\%) were most frequently affected by tenderness, whereas of the joints of the upper limbs, the greatest percentages of joint tenderness were observed in the wrists $(28 \%)$ and shoulders (27\%). Similarly, of the joints of the lower limbs, the greatest percentages of joint swelling were reported for knees (25\%) and ankles (22\%) compared with $19 \%$ for the wrists. (The hips were not evaluated for swelling.) For fingers and toes, swelling was more frequently reported for the metacarpophalangeal joints and proximal interphalangeal joints (4\% to $17 \%)$ than for the metatarsophalangeal (MTP) joints (1\% to $6 \%$ ), probably because swelling in the MTP joints is difficult to evaluate. The median TJCs were 4 for 175 male patients and 7 for 106 female patients, 5 for 217
HLA-B27-positive patients and 6 for 57 HLA-B27-negative patients, and 4 for 170 patients not receiving concomitant DMARD therapy and 6 for 111 receiving concomitant DMARD therapy. The median SJC was 2, regardless of sex, HLA-B27, and DMARD treatment.

\section{Adalimumab effectiveness at week 12 \\ Enthesitis}

For patients with MASES of at least 1 at baseline, the median MASES decreased from 5 at baseline to 1 at week 12; the median change in MASES from baseline to week 12 was -2 (Table 3 ). The median MASESs at week 12 were 1 for women (median reduction, -3) and 0 for men (median reduction, -2 ). The improvement in MASES was independent of HLA-B27 positivity and 
Table 3 MASES, tender joint count, and swollen joint count by sex, HLA-B27 positivity, and concomitant DMARD use

\begin{tabular}{|c|c|c|c|c|c|c|c|}
\hline & All & Male & Female & $\begin{array}{l}\text { HLA-B27- } \\
\text { negative }\end{array}$ & $\begin{array}{l}\text { HLA-B27- } \\
\text { positive }\end{array}$ & $\begin{array}{l}\text { No concomitant DMARD at } \\
\text { baseline }\end{array}$ & $\begin{array}{c}\text { Concomitant DMARD at } \\
\text { baseline }\end{array}$ \\
\hline & \multicolumn{7}{|c|}{$\begin{array}{c}\text { Median } \\
\text { First quartile, third quartile } \\
{[95 \% \text { confidence interval] }}\end{array}$} \\
\hline \multicolumn{8}{|c|}{ Patients with enthesitis, MASES $\geq 1$ at baseline } \\
\hline $\begin{array}{l}\text { MASES: } 0 \text { to } 13, \text { number } \\
\text { (percentage) }\end{array}$ & $\begin{array}{c}667 \\
(100) \\
\end{array}$ & $\begin{array}{c}431 \\
(64.6) \\
\end{array}$ & $\begin{array}{c}236 \\
(35.4)\end{array}$ & $\begin{array}{c}126 \\
(18.9)^{\mathrm{a}}\end{array}$ & $\begin{array}{c}523 \\
(78.4)^{\mathrm{a}} \\
\end{array}$ & $\begin{array}{c}499 \\
(74.8)\end{array}$ & $\begin{array}{c}168 \\
(25.2)\end{array}$ \\
\hline Baseline & $\begin{array}{c}5 \\
2,8 \\
\end{array}$ & $\begin{array}{c}4 \\
2,7 \\
\end{array}$ & $\begin{array}{c}7 \\
4,9 \\
\end{array}$ & $\begin{array}{c}5 \\
2,9 \\
\end{array}$ & $\begin{array}{c}5 \\
2,8 \\
\end{array}$ & $\begin{array}{c}5 \\
2,8 \\
\end{array}$ & $\begin{array}{c}4 \\
2,8 \\
\end{array}$ \\
\hline Week 12 & $\begin{array}{c}1 \\
0,4\end{array}$ & $\begin{array}{c}0 \\
0,2\end{array}$ & $\begin{array}{l}1 \\
0,5\end{array}$ & $\begin{array}{c}1 \\
0,5\end{array}$ & $\begin{array}{c}0 \\
0,3\end{array}$ & $\begin{array}{c}0 \\
0,3\end{array}$ & $\begin{array}{c}1 \\
0,4\end{array}$ \\
\hline $\begin{array}{l}\text { Change from baseline to } \\
\text { week } 12\end{array}$ & $\begin{array}{c}-2 \\
-5,-1 \\
{[-3 \text { to }} \\
-2]\end{array}$ & $\begin{array}{c}-2 \\
-5,-1 \\
{[-3 \text { to }} \\
-2]\end{array}$ & $\begin{array}{c}-3 \\
-6,-1 \\
{[-4 \text { to }} \\
-2]\end{array}$ & $\begin{array}{c}-2 \\
-5,-1 \\
{[-3 \text { to }-2]}\end{array}$ & $\begin{array}{c}-3 \\
-6,-1 \\
{[-3 \text { to }-2]}\end{array}$ & $\begin{array}{c}-3 \\
-5,-1 \\
{[-3 \text { to }-2]}\end{array}$ & $\begin{array}{c}-2 \\
-5,-1 \\
{[-5 \text { to }-2]}\end{array}$ \\
\hline \multicolumn{8}{|c|}{ Patients with peripheral arthritis, SJC $\geq 1$ at baseline } \\
\hline $\begin{array}{l}\text { TJC: } 0 \text { to } 46 \text {, number } \\
\text { (percentage) }\end{array}$ & $\begin{array}{c}281 \\
(100)\end{array}$ & $\begin{array}{c}175 \\
(62.2)\end{array}$ & $\begin{array}{c}106 \\
(37.7)\end{array}$ & $\begin{array}{c}57 \\
(20.3)^{\mathrm{a}}\end{array}$ & $\begin{array}{c}217 \\
(77.2)^{\mathrm{a}}\end{array}$ & $\begin{array}{c}170 \\
(60.5)\end{array}$ & $\begin{array}{c}111 \\
(39.5)\end{array}$ \\
\hline Baseline & $\begin{array}{c}5 \\
2,12\end{array}$ & $\begin{array}{c}4 \\
2,10\end{array}$ & $\begin{array}{c}7 \\
3,14\end{array}$ & $\begin{array}{c}6 \\
3,13\end{array}$ & $\begin{array}{c}5 \\
2,12\end{array}$ & $\begin{array}{c}4 \\
2,10\end{array}$ & $\begin{array}{c}6 \\
3,13\end{array}$ \\
\hline Week 12 & $\begin{array}{c}1 \\
0,3\end{array}$ & $\begin{array}{c}1 \\
0,3\end{array}$ & $\begin{array}{c}1 \\
0,4\end{array}$ & $\begin{array}{c}1 \\
0,4\end{array}$ & $\begin{array}{c}0 \\
0,3\end{array}$ & $\begin{array}{c}0 \\
0,3\end{array}$ & $\begin{array}{c}1 \\
0,4\end{array}$ \\
\hline $\begin{array}{l}\text { Change from baseline to } \\
\text { week } 12\end{array}$ & $\begin{array}{c}-3 \\
-8,-1 \\
{[-4 \text { to }} \\
-2]\end{array}$ & $\begin{array}{c}-2 \\
-6,-1 \\
{[-3 \text { to }} \\
-2]\end{array}$ & $\begin{array}{c}-4 \\
-10,-2 \\
{[-6 \text { to }} \\
-3]\end{array}$ & $\begin{array}{c}-3 \\
-10,-1 \\
{[-6 \text { to }-2]}\end{array}$ & $\begin{array}{c}-3 \\
-7,-1 \\
{[-4 \text { to }-2]}\end{array}$ & $\begin{array}{c}-2 \\
-7,-1 \\
{[-3 \text { to }-2]}\end{array}$ & $\begin{array}{c}-3 \\
-9,-2 \\
{[-4 \text { to }-2]}\end{array}$ \\
\hline $\begin{array}{l}\text { SJC: } 0 \text { to } 44 \text {, number } \\
\text { (percentage) }\end{array}$ & $\begin{array}{l}281 \\
(100)\end{array}$ & $\begin{array}{c}175 \\
(62.2)\end{array}$ & $\begin{array}{c}106 \\
(37.7)\end{array}$ & $\begin{array}{c}57 \\
(20.3)^{\mathrm{a}}\end{array}$ & $\begin{array}{c}217 \\
(77.2)^{\mathrm{a}}\end{array}$ & $\begin{array}{l}170 \\
(60.5)\end{array}$ & $\begin{array}{c}111 \\
(39.5)\end{array}$ \\
\hline Baseline & $\begin{array}{c}2 \\
1,4\end{array}$ & $\begin{array}{c}2 \\
1,3\end{array}$ & $\begin{array}{c}2 \\
1,6\end{array}$ & $\begin{array}{c}2 \\
1,6\end{array}$ & $\begin{array}{c}2 \\
1,4\end{array}$ & $\begin{array}{c}2 \\
1,3\end{array}$ & $\begin{array}{c}2 \\
1,6\end{array}$ \\
\hline Week 12 & $\begin{array}{c}0 \\
0,1\end{array}$ & $\begin{array}{c}0 \\
0,1\end{array}$ & $\begin{array}{c}0 \\
0,1\end{array}$ & $\begin{array}{c}0 \\
0,1\end{array}$ & $\begin{array}{c}0 \\
0,1\end{array}$ & $\begin{array}{c}0 \\
0,1\end{array}$ & $\begin{array}{c}0 \\
0,1\end{array}$ \\
\hline $\begin{array}{l}\text { Change from baseline to } \\
\text { week } 12\end{array}$ & $\begin{array}{c}-1 \\
-3,-1 \\
{[-2 \text { to }} \\
-1]\end{array}$ & $\begin{array}{c}-1 \\
-3,-1 \\
{[-2 \text { to }} \\
-1]\end{array}$ & $\begin{array}{c}-2 \\
-4,-1 \\
{[-2 \text { to }} \\
-1]\end{array}$ & $\begin{array}{c}-1 \\
-4,-1 \\
{[-2 \text { to }-1]}\end{array}$ & $\begin{array}{c}-1 \\
-3,-1 \\
{[-2 \text { to }-1]}\end{array}$ & $\begin{array}{c}-1 \\
-2,-1 \\
{[-1 \text { to }-1]}\end{array}$ & $\begin{array}{c}-2 \\
-4,-1 \\
{[-2 \text { to }-2]}\end{array}$ \\
\hline
\end{tabular}

aecause of missing data, the percentages of patients with HLA-B27 status do not sum to 100\%. DMARD, disease-modifying antirheumatic drug; MASES, Maastricht Ankylosing Spondylitis Enthesitis Score; SJC, swollen joint count; TJC, tender joint count.

concomitant DMARD therapy. Enthesitis of the plantar fascia resolved in 122 of 173 (70.5\%) patients (77 men and 45 women) at week 12 . Overall, similar improvements in enthesitis were observed across enthesitis sites (Figure 2).

\section{Peripheral arthritis}

After 12 weeks of treatment with adalimumab, the TJC for 281 patients with peripheral arthritis (SJC of at least 1) decreased from a median of 5 at baseline to 1 , with a median reduction of -3 (Table 3 ). The SJC improved from a median of 2 at baseline to 0 at week 12, with a median reduction of -1 . Rapid improvement in peripheral arthritis was observed, with reductions in the median TJC and SJC documented after a single injection of adalimumab; at week 2, the median TJC was 2 and the median SJC was 0.

\section{Overall}

As shown in Figure 3, the percentage of patients achieving ASAS20 response at week 12 was lowest in the subgroup of patients with both enthesitis and peripheral arthritis $(66.7 \%)$ at baseline compared with the other patient subgroups (68.0 to $71.0 \%$ ), whereas the percentage achieving ASAS40 response was lower in the subgroup with peripheral arthritis and no enthesitis $(46.0 \%)$ compared with the others (50.6\% to $56 \%)$. Similarly, the percentage achieving a BASDAI50 response was lower in patients with peripheral arthritis and no enthesitis (52.9\%) than in other subgroups (54.9\% to 61.5\%). Median changes from baseline to week 12 and 95\% CIs in BASDAI, BASFI, PaGA, and CRP were similar between patient subgroups $(P>0.8)$ (Table 2). 


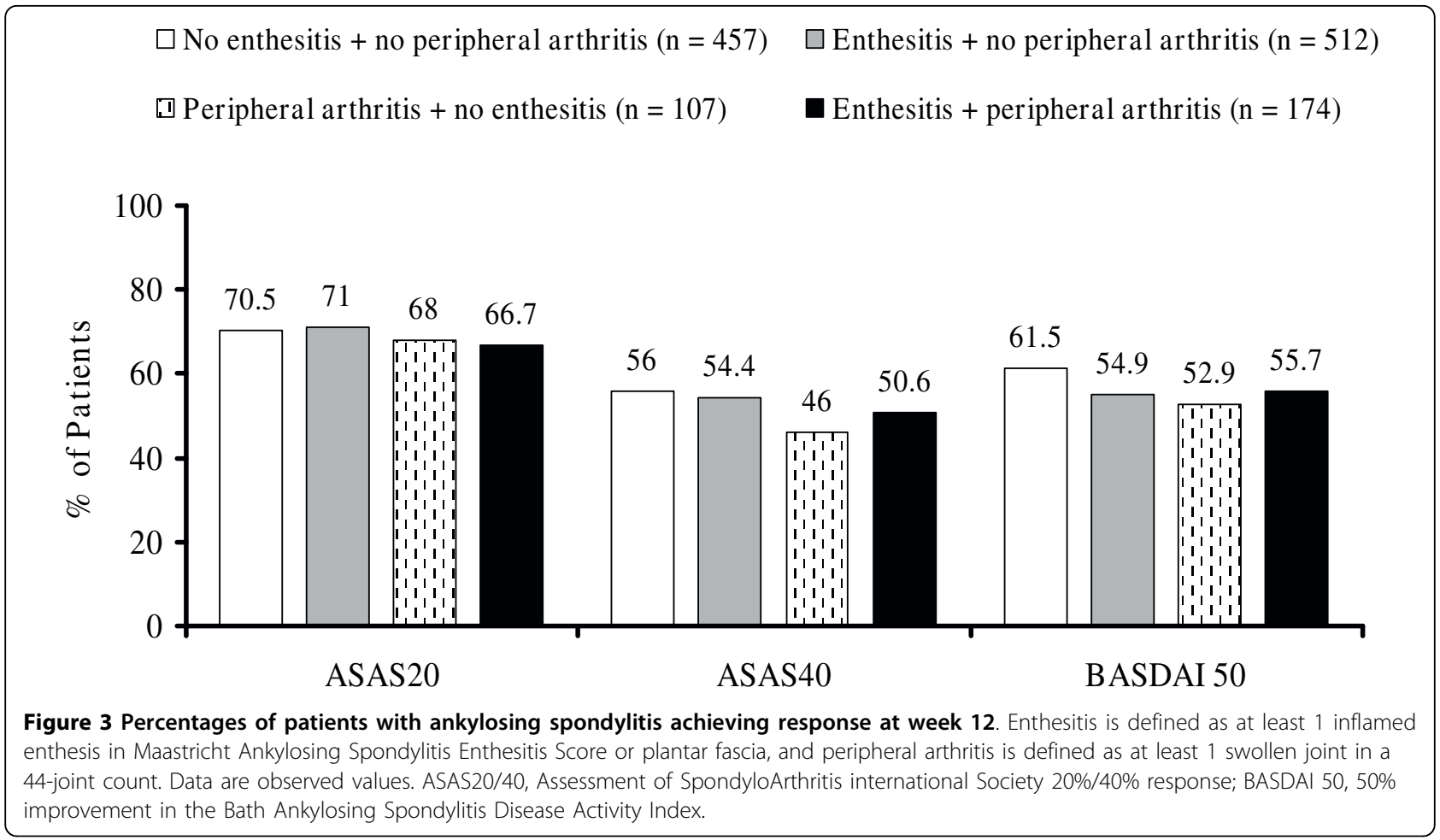

Correlation between improvements in axial disease and improvements in enthesitis or peripheral arthritis or both Improvement in AS disease activity and functional status, measured by BASDAI and BASFI, respectively, did not correlate with improvement in enthesitis, measured by MASES and inflammation of the plantar fascia, or improvement in peripheral arthritis, measured by TJC and by SJC. Spearman rank order correlation coefficients ranged from 0.03 to 0.24 across evaluations of the various combinations of measures.

\section{Discussion}

Adalimumab effectiveness and safety were investigated in a large cohort of patients with AS in an open-label, uncontrolled, multinational study designed to reflect routine rheumatology practice [1]. The patients had long-standing, active AS with a broad range of disease manifestations typically associated with AS and were considered eligible for TNF-antagonist therapy [9]. Herein, we specifically assessed the effectiveness of adalimumab in AS patients with or without enthesitis or peripheral arthritis. The baseline frequency of current enthesitis (54.9\%) in this population and that reported in a previous adalimumab RCT (74\%) [15] are both markedly greater than the frequency reported in recent national observational studies (15\% to $30 \%)$ [1-3], whereas the rate of current peripheral arthritis found in this study was in accordance with rates reported in the literature [2].
In this study, adalimumab therapy was associated with substantial improvement in enthesitis from baseline to week 12, as indicated by changes in MASES, and in inflammation across all examined entheses, including the plantar fascia. Our results are consistent with results of a previous RCT of adalimumab in 315 patients with AS [15] and with an RCT of infliximab [14], although comparison with the latter trial is limited by the use of disparate enthesitis scores.

In the present study, peripheral arthritis in the 281 patients who had at least 1 swollen joint at baseline improved rapidly and substantially during adalimumab therapy, with half of the patients reporting no swollen joints at week 12 (week-12 median TJC = 1 and SJC = 0). Because of the skewed distribution of values, median data are presented here. In a previous adalimumab RCT in which mean data were published [15], the mean change at week 12 in TJC was -0.8 and the mean change in SJC was -0.4 . By comparison, in our study, the mean changes from baseline to week 12 were -4.9 for TJC and -2.9 for SJC, and the median changes were lower than these mean changes (TJC, -3 and SJC, -1). Significant decreases in TJC and SJC from baseline to week 12 have been reported for infliximab therapy for AS [10].

Women with AS had a greater number of inflamed joints and inflamed entheses at baseline than men. Although the presence of coexisting fibromyalgia in some of the female patients cannot be excluded, the pattern of enthesitis localization as measured by MASES 
and examination of the plantar fascia is typical for enthesitis in AS (Figure 2) [21,26]. Moreover, the finding that female patients improved as much as male patients after 12 weeks of adalimumab therapy suggests that coexisting fibromyalgia did not contribute substantially to the greater enthesitis count at baseline in women. The frequency of and improvement in enthesitis and peripheral arthritis appeared to be unaffected by HLAB27 status and concomitant DMARD therapy.

The burden of disease at baseline, as measured by BASDAI, BASFI, and PaGA, was lower for patients with no enthesitis and no peripheral arthritis than for patients with either one or both of these manifestations $(P<0.005)$. These results are in accordance with previous literature reports $[7,27,28]$. Of note, two studies showed that a greater BASDAI in patients with peripheral arthritis was not associated with the joint-specific BASDAI items [27,29]. Although disease activity and physical impairment differed notably at baseline, the magnitude of improvement with adalimumab therapy in patients with enthesitis or peripheral arthritis or both was similar to that observed for patients without these extra-axial manifestations. At week 12, the median changes in BASDAI, BASFI, PaGA, and CRP were similar between all of the various subgroups, and no important differences in the degree of improvement were detected. However, slightly greater ASAS40 and BASDAI 50 response rates were observed for patients with no enthesitis and no arthritis than for those with enthesitis or arthritis or both. The results of this study of patients with AS categorized by enthesitis and arthritis are consistent with previous predictor analyses, which found that enthesitis and arthritis did not influence the effect of TNF-antagonist therapy [1].

We did not detect any correlation between improvement in BASDAI and BASFI with improvement in enthesitis or peripheral arthritis. In comparison with joint counts and enthesitis counts, which capture a single domain of AS that may entirely resolve, BASDAI and BASFI capture many disease domains of AS, each of which may respond differently to therapy.

\section{Conclusions}

In this large cohort of patients with active AS, adalimumab treatment effectively reduced enthesitis and peripheral arthritis. Although the burden of disease is greater when AS is associated with enthesitis or peripheral arthritis or both, patients with these extra-axial manifestations benefited from adalimumab treatment as much as patients with axial disease only.

\section{Abbreviations}

AS: ankylosing spondylitis; ASAS20/40: Assessment of SpondyloArthritis international Society 20\%/40\% response; BASDAl: Bath Ankylosing Spondylitis
Disease Activity Index; BASDAI 50: 50\% improvement in the Bath Ankylosing Spondylitis Disease Activity Index; BASFl: Bath Ankylosing Spondylitis Functional Index; Cl: confidence interval; CRP: C-reactive protein; DMARD: disease-modifying antirheumatic drug; MASES: Maastricht Ankylosing Spondylitis Enthesitis Score; MTP: metatarsophalangeal; NSAID: nonsteroidal anti-inflammatory drug; PaGA: Patient's Global Assessment of disease activity; RCT: randomized controlled trial; RHAPSODY: Review of Safety and Effectiveness with Adalimumab in Patients with Active Ankylosing Spondylitis; SJC: swollen joint count; TJC: tender joint count; TNF: tumor necrosis factor.

\section{Acknowledgements}

The authors thank all investigators and research nurses who contributed to patient recruitment and data collection in the RHAPSODY study. We also acknowledge the contributions of the staff at the following sites that have enrolled at least five patients with AS: Austria: Omid Zamani (Wien), Manfred Herold (Innsbruck); Belgium: Jean-Pol Dufour (Charleroi), Martin Maertens (Oostende), Filip van den Bosch (Belsele), Paul van Wanghe (Hasselt), Johan Vanhoof (Genk), Eric Veys (Gent); Denmark: Karin Grau (Kolding), Palle Holck (Silkeborg); Finland: Pentti Jaervinen (Hyvinkää), Timo Yli-Kerttula (Turku); France: Claude Benhamou (Orleans), Thierry Billey (Cahors), Maxime Breban (Boulogne), Pascal Claudepierre (Creteil), Bernard Combe (Montpellier), Xavier Deprez (Valenciennes), Liana Euller-Ziegler (Nice), Patrice Fardellone (Amiens), Pierre Fauquert (Berck), René-Marc Flipo (Lille), Jean Godde (Marseille), Philippe Goupille (Tours), J-Jean-Luc Grauer (Aix-en-Provence), Pascal Hilliquin (Corbeil Essonnes), Christian Jorgensen (Montpellier), André Kahan (Paris), Xavier Mariette (Le Kremlin-Bicêtre), Yves Maugars (Nantes), Pierre Miossec (Lyon), Alain Saraux (Brest), Jean-Louis Siame (Levin), Jean Sibilia (Strasbourg), Jaques Tebib (Lyon), Charles Zarnitsky (Montvillier); Germany: Stefan Bornstein (Dresden), Jürgen Braun (Herne), Harald Burkhardt (Frankfurt), Edmund Edelmann (Bad Aibling), A Engel (Stuttgart), Georg Gauler (Osnabrück), Gert Hein (Jena), Maria Höhle (Hamburg), Andreas Kapelle (Hoyerswerda), Herbert Kellner (München), Jörn Kekow (Vogelsang), Thilo Klopsch (Neubrandenburg), Ina Kötter (Tübingen), Andreas Krause (Berlin), Klaus Krüger (München), Brigitte Krummel-Lorenz (Frankfurt), Johannes Lohmann (Bad Bentheim), Lothar Meier (Hofheim), Ulf MüllerLadner (Bad Nauheim), Gunther Neeck (Rostock), Hans-Hartmut Peter (Freiburg), Constanze Richter (Stuttgart), Matthias Richter (Rostock), Karin Rockwitz (Goslar), Ekkehard Röther (Villingen-Schwenningen), Andrea Rubbert-Roth (Köln), Martin Rudwaleit (Berlin), A Seifert (Berlin), Wolfgang Spieler (Zerbst), Rrainer Sprekeler (Zeven), Hans-Peter Tony (Würzburg), Harald Tremel (Hamburg), Ulrich von Hinüber (Hildesheim), Jürgen Wollenhaupt (Hamburg), Silke Zinke (Berlin); Greece: Spyros Aslanidis (Patras), Kyriaki Boki (Athens), Dimitrios Boumpas (Heraklion), Michail Daniilidis (Thessaloniki), Lazaros Sakkas (Larisa), Petros Sfikakis (Athens); Italy: Fabrizio Cantini (Prato), Gianfranco Ferraccioli (Roma), Alessandro Mathieu (Monserrato), Marco Matucci Cerinic (Firenze), Ignazio Olivieri (Potenza), Carlo Salvarani (Reggio Emilia), Giovanni Triolo (Palermo), Guido Valesini (Roma); The Netherlands: Eduard Nicolaas Griep (Leeuwarden), Joanna Rosalia Maria Griep-Wentink (Den Helder), Steffen Zanen (Zwolle); Norway: Erik Rødevand (Trondheim); Spain: Alberto Alonso (Barakaldo), Melchor Alvarez Vega (Madrid), Maria Brito (Madrid), L Carreno (Madrid), Maria del Pilar Fernandez Dapica (Madrid), Jose Luis Fernandez-Sueiro (Elche), Eduardo Loza Cortina (Pamplona), Carlos Rodriguez Lozano (Las Palmas de Gran Canaria), José A. Roman Ivorra (Valencia), Agusti Sellas (Barcelona), Juan Carlos Torre (Oviedo), Juan Tovar Beltran (Elche); Sweden: Awat Jalal (Öerebro), Åke Thörner (Eskilstuna); Switzerland: Beat Michel (Zürich), R Theiler (Zürich), Peter Villiger (Bern); UK: Mohammed Akil (Sheffield), Ernest Choy (London), Robert Cooper (Manchester), Christopher Edwards (Southampton), Paul Emery (Leeds), Karl Gaffney (Norwich), Emmanuel George (Merseyside), David Grennan (Wigan), Richard Hull (Portsmouth), Paresh Jobanputra (Birmingham), Lesley Kay (Newcastle), Andrew Keat (Harrow), Bruce Kirkham (London), Robert Moots (Liverpool), Andrew Ostor (Cambridge), Millicent Stone (Bath), Paul Wordsworth (Oxford). We thank loanna Mantika for study management (Abbott Laboratories, UK), Christa Zaiti-Runkel for data management, Angelika Freitag and Anja Bruhn for statistical programming (Abbott GmbH \& Co. KG), and Dana L Randall (Arbor Communications, Inc., Ann Arbor, MI, USA) and Michael A Nissen (Abbott Laboratories) for writing and editing support in the development and revision of this manuscript. This support was funded by Abbott. Abbott Laboratories funded the research reported in this manuscript and the manuscript's preparation. The RHAPSODY Study 
Group included experts from academic institutions in Europe and the US and members of Abbott Laboratories, who were responsible for the design of the original clinical trial. Collection and analyses of clinical data were performed by Abbott Laboratories.

\section{Author details}

${ }^{1}$ Charité-University Medicine Berlin, Benjamin Franklin Campus, Medical Department I, Rheumatology, Hindenburgdamm 30, 12203 Berlin, Germany. ${ }^{2}$ Service de Rhumatologie, Hôpital Henri Mondor-APHP, Université Paris XII, avenue du Maréchal de Lattre de Tassigny 51, 94010 Créteil, France. ${ }^{3} \mathrm{Abbott}$ $\mathrm{GmbH} \&$ Co KG, Knollstraße 50, 67061 Ludwigshafen, Germany. ${ }^{4}$ University of Medicine and Dentistry of New Jersey, 189 New Street, New Brunswick, NJ 08901-1954, USA. ${ }^{5}$ Formerly Abbott Laboratories, Parsippany, NJ, USA.

\section{Authors' contributions}

All authors contributed to manuscript development and reviewed and approved the content of the submitted manuscript.

\section{Competing interests}

MR and PC were RHAPSODY study investigators. MR has received consulting fees, speaking fees, and honoraria from Abbott, MSD (München, Germany), Schering-Plough Corporation (Kenilworth, NJ, USA), Pfizer Inc (New York, NY, USA), and Wyeth (Madison, NJ, USA). MK and HK are employees of Abbott $\mathrm{GmbH} \&$ Co KG (Ludwigshafen, Germany), an affiliate of Abbott Laboratories, and hold shares of Abbott stock. SK is a contractor of Abbott GmbH \& Co KG. RW was an employee of Abbott Laboratories at the time this study and these analyses were completed and holds shares of Abbott stock.

Received: 4 November 2009 Revised: 8 February 2010

Accepted: 15 March 2010 Published: 15 March 2010

\section{References}

1. Rudwaleit M, Claudepierre P, Wordsworth P, Cortina EL, Sieper J, Kron M, Carcereri-De-Prati R, Kupper H, Kary S: Effectiveness, safety, and predictors of good clinical response in 1250 patients treated with adalimumab for active ankylosing spondylitis. J Rheumatol 2009, 36:801-808.

2. Cruyssen Vander B, Ribbens C, Boonen A, Mielants $H$, de Vlam K, Lenaerts J, Steinfeld S, Bosch Van den F, Dewulf L, Vastesaeger N: The epidemiology of ankylosing spondylitis and the commencement of anti-TNF therapy in daily rheumatology practice. Ann Rheum Dis 2007, 66:1072-1077.

3. Collantes E, Zarco P, Muñoz E, Juanola X, Mulero J, Fernández-Sueiro JL, Torre-Alonso JC, Gratacós J, González C, Batlle E, Fernández P, Linares LF, Brito $E$, Carmona L: Disease pattern of spondyloarthropathies in Spain: description of the first national registry (REGISPONSER) extended report. Rheumatology 2007, 46:1309-1315.

4. Rudwaleit M, Haibel H, Baraliakos X, Listing J, Märker-Hermann E, Zeidler $H_{\text {, }}$ Braun J, Sieper J: The early disease stage in axial spondyloarthritis: results from the German spondyloarthritis inception cohort. Arthritis Rheum 2009, 60:717-727.

5. Brophy S, Calin A: Ankylosing spondylitis: interaction between genes, joints, age at onset, and disease expression. J Rheumatol 2001, 28:2283-2288

6. Boonen A, van der Linden SM: The burden of ankylosing spondylitis. $J$ Rheumatol Suppl 2006, 78:4-11.

7. Braun J, van der Heijde D, Dougados M, Emery P, Khan MA, Sieper J, van der Kinden S: Staging of patients with ankylosing spondylitis: a preliminary proposal. Ann Rheum Dis 2002, 61 Suppl 3:iii9-iii23.

8. Sidiropoulos PI, Hatemi G, Song I-H, Avouac J, Collantes E, Hamuryudan V, Herold M, Kvien TK, Mielants H, Mendoza JM, Olivieri I, Østergaard M, Schachna L, Sieper J, Boumpas DT, Dougados M: Evidence-based recommendations for the management of ankylosing spondylitis: systemic literature search of the $3 \mathrm{E}$ Initiative in Rheumatology involving a broad panel of experts and practising rheumatologists. Rheumatology 2008, 47:355-361.

9. Zochling J, Heijde van der D, Dougados M, Braun J: Current evidence for the management of ankylosing spondylitis: a systematic literature review for the ASAS/EULAR management recommendations in ankylosing spondylitis. Ann Rheum Dis 2006, 65:423-432.

10. Bosch van den F, Kruithof E, Baeten D, Herssens A, de Keyser F, Mielants H, Veys EM: Randomized double-blind comparison of chimeric monoclonal antibody to tumor necrosis factor alpha (infliximab) versus placebo in active spondyloarthropathy. Arthritis Rheum 2002, 46:755-765.

11. Gorman JD, Sack KE, Davis JC Jr: Treatment of ankylosing spondylitis by inhibition of tumor necrosis factor alpha. N Engl J Med 2002, 346:1349-1356.

12. Braun J, Brandt J, Listing J, Zink A, Alten R, Golder W, Gromnica-Ihle E, Kellner H, Krause A, Schneider M, Sörensen H, Zeidler H, Thriene W, Sieper J: Treatment of active ankylosing spondylitis with infliximab: a randomized controlled multicentre trial. Lancet 2002, 359:1187-1193.

13. Braun J, Baraliakos X, Brandt J, Listing J, Zink A, Alten R, Burmester G, Gromnica-Ihle E, Kellner $H$, Schneider M, Sörensen $H$, Zeidler $H$, Sieper J: Persistent clinical response to the anti-TNF-alpha antibody infliximab in patients with ankylosing spondylitis over 3 years. Rheumatology (Oxford) 2005, 44:670-676.

14. Heijde van der D, Dijkmans B, Geusens P, Sieper J, DeWoody K, Williamson P, Braun J, Ankylosing Spondylitis Study for the Evaluation of Recombinant Infliximab Therapy Study Group: Efficacy and safety of infliximab in patients with ankylosing spondylitis: results of a randomized, placebo-controlled trial (ASSERT). Arthritis Rheum 2005, 52:582-591.

15. Heijde van der D, Kivitz A, Schiff MH, Sieper J, Dijkmans BA, Braun J, Dougados M, Reveille JD, Wong RL, Kupper H, Davis JC Jr, ATLAS Study Group: Efficacy and safety of adalimumab in patients with ankylosing spondylitis. Arthritis Rheum 2006, 54:2136-2146.

16. Calin A, Dijkmans BA, Emery P, Hakala M, Kalden J, Leirisalo-Repo M Mola EM, Salvarani C, Sanmartí R, Sany J, Sibilia J, Sieper J, Linden van der S, Veys E, Appel AM, Fatenejad S: Outcomes of a multicentre randomized clinical trial of etanercept to treat ankylosing spondylitis. Ann Rheum Dis 2004, 63:1594-1600.

17. Davis JC Jr, Heijde van der D, Braun J, Dougados M, Cush J, Clegg DO, Kivitz A, Fleischmann R, Inman R, Tsuji W, Enbrel Ankylosing Spondylitis Study Group: Recombinant human tumor necrosis factor receptor (etanercept) for treating ankylosing spondylitis: a randomized, controlled trial. Arthritis Rheum 2003, 48:3230-3236.

18. Furst DE, Keystone EC, Kirkham B, Kavanaugh A, Fleischmann R, Mease P, Breedveld FC, Smolen JS, Kalden JR, Burmester GR, Braun J, Emery P, Winthrop K, Bresnihan B, De Benedetti F, Dörner T, Gibofsky A, Schiff MH, Sieper J, Singer N, Van Riel PL, Weinblatt ME, Weisman MH: Updated consensus statement on biological agents for the treatment of rheumatic diseases, 2008. Ann Rheum Dis 2008, 67(Suppl 3):iii2-iii25, A published correction appears in Ann Rheum Dis 2009, 68:452..

19. Linden van der S, Valkenburg HA, Cats A: Evaluation of diagnostic criteria for ankylosing spondylitis: a proposal for modification of the New York criteria. Arthritis Rheum 1984, 27:361-368.

20. Garrett S, Jenkinson T, Kennedy LG, Whitelock H, Gaisford P, Calin A: A new approach to defining disease status in ankylosing spondylitis: the Bath Ankylosing Spondylitis Disease Activity Index. J Rheumatol 1994, 21:2286-2291.

21. Heuft-Dorenbosch $L$, Spoorenberg $A$, van Tubergen $A$, Landewé $R$, van ver Tempel H, Mielants H, Dougados M, Heijde van der D: Assessment of enthesitis in ankylosing spondylitis. Ann Rheum Dis 2003, 62:127-132.

22. Anderson JJ, Baron G, Heijde van der D, Felson DT, Dougados M: Ankylosing spondylitis assessment group preliminary definition of shortterm improvement in ankylosing spondylitis. Arthritis Rheum 2001, 44:1876-1886

23. Braun J, Pham T, Sieper J, Davis J, Linden van der S, Dougados M, Heijde van der D, ASAS Working Group: International ASAS consensus statement for the use of anti-tumour necrosis factor agents in patients with ankylosing spondylitis. Ann Rheum Dis 2003, 62:817-824.

24. Braun J, Davis J, Dougados M, Sieper J, Linden van der S, Heijde van der D, ASAS Working Group: First update of the international ASAS consensus statement for the use of anti-TNF agents in patients with ankylosing spondylitis. Ann Rheum Dis 2006, 65:316-320.

25. Calin A, Garrett S, Whitelock H, Kennedy LG, O'Hea J, Mallorie P, Jenkinson T: A new approach to defining functional ability in ankylosing spondylitis: the development of the Bath Ankylosing Spondylitis Functional Index. J Rheumatol 1994, 21:2281-2285.

26. Aloush V, Ablin JN, Reitblat T, Caspi D, Elkayam O: Fibromyalgia in women with ankylosing spondylitis. Rheumatol Int 2007, 27:865-868.

27. Heuft-Dorenbosch L, van Tubergen A, Spoorenberg A, Landewé R, Dougados M, Mielants H, Tempel van der H, Heijde van der D: The 
influence of peripheral arthritis on disease activity in ankylosing spondylitis patients as measured with the Bath ankylosing spondylitis disease activity index. Arthritis Rheum 2004, 51:154-159.

28. Sivas F, Mermerci Başkan B, Erkol Inal E, Akbulut Aktekin L, Barça N, Ozoran K, Bodur H: The relationship between enthesitis indices and disease activity parameters in patients with ankylosing spondylitis. Clin Rheumatol 2009, 28:259-264.

29. Song $\mathbb{H}$, Rudwaleit M, Listing J, Sieper J: Comparison of the Bath Ankylosing Spondylitis Disease Activity Index and the modified version of the index in assessing disease activity in patients with ankylosing spondylitis without peripheral manifestations. Ann Rheum Dis 2009, 68:1701-1707.

doi:10.1186/ar2953

Cite this article as: Rudwaleit et al:: Effectiveness of adalimumab in treating patients with ankylosing spondylitis associated with enthesitis and peripheral arthritis. Arthritis Research \& Therapy 2010 12:R43.

\section{Submit your next manuscript to BioMed Central} and take full advantage of:

- Convenient online submission

- Thorough peer review

- No space constraints or color figure charges

- Immediate publication on acceptance

- Inclusion in PubMed, CAS, Scopus and Google Scholar

- Research which is freely available for redistribution

Submit your manuscript at www.biomedcentral.com/submit 